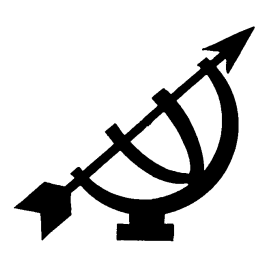

\title{
Die geborgenheid van die onderwyser as voorwaarde vir opvoedende skoolonderwys
}

\section{I.J. Oosthuizen}

Nagraadse Skool vir Opvoedkunde

Fakulteit Opvoedingswetenskappe

Potchefstroomse Universiteit vir $\mathrm{CHO}$

POTCHEFSTROOM

2520

E-pos: snoijo@puknet.puk.ac.za

P.J. Mentz

Skool vir Opvoedkundige Opleiding en Ontwikkeling

Fakulteit Opvoedingswetenskappe

Potchefstroomse Universiteit vir $\mathrm{CHO}$

POTCHEFSTROOM

2520

E-pos: soopjm@puknet.puk.ac.za

J.L. van der Walt

Nagraadse Skool vir Opvoedkunde

Fakulteit Opvoedingswetenskappe

$\mathrm{PU}$ vir $\mathrm{CHO}$

POTCHEFSTROOM

2520

E-pos: jlvdwalt@intekom.co.za

Abstract

Teacher security as a pre-condition for adding pedagogical value to teaching in schools

Since 1994 the new political dispensation in South Africa has led to several disruptions in the education system. Teachers have not escaped the effects of this disruption, and many teachers manifest symptoms of insecure behaviour. Because of their insecurity, many teachers are unable to add pedagogical value to their teaching efforts. The disruption they are currently experiencing is, however, by no means more radical or acute than in other periods in South African history. A number of guidelines are offered by means of which (teachers' perceptions of) teacher security can be improved. This is done on the premise that strengthening teacher 
security and safety will not only enable teachers to understand their divine calling as well as the nature of pedagogical involvement with learners, but will indeed motivate them to also apply pedagogical principles and insight in actual classroom practice.

\section{Inleiding en probleemstelling}

Die formele onderwys in Suid-Afrika is gedurende die afgelope meer as drie eeue telkens gekenmerk deur vorme van woeling en onstabiliteit. Die staatkundig-politieke onstabiliteit van elke tydsgewrig in die land se onderwysgeskiedenis het tot ontwrigting by die onderwysers van die bepaalde tyd gelei. 'n Mens kan jou skaars groter ontwrigting in die onderwys indink as in die periode tussen 1976 en 1994, toe spesifiek die onderwys deur die teenstanders van die destydse staatkundig-politieke orde gebruik is om die status quo tot 'n einde te bring. Nie slegs die leerders en hulle skoolloopbane is in hierdie byna twee dekades ernstig ontwrig en aan bande gelê nie, maar ook hulle ouers en onderwysers het die woelinge aan eie lyf gevoel. Die situasie waarin talle onderwysers hulle destyds bevind het, is haas onvoorstelbaar: diegene wat in diens van die Departement van Onderwys en Opleiding was, het hulle onvermydelik in die knyptang van die gemeenskap aan die een kant, en die staat/onderwysowerheid aan die ander kant bevind. Baie was selfs van hulle fisiese veiligheid nie seker nie. Van fisiese en psigologiese veiligheid in die skoolopset en in die klaskamer was nie veel sprake nie. Van hulle taak om onderwys te gee het in baie gevalle nie veel gekom nie. Frustrasie, onsekerheid en woede was by baie onderwysers aan die orde van die dag.

Onderwysers in die ander departemente het op hulle beurt ' $n$ onseker toekoms in die gesig gestaar, en woelinge ten gunste of téén 'n moontlike nuwe politieke en onderwysbedeling het die skoollewe gekenmerk.

Die aanbreek van die nuwe staatkundig-politieke bedeling in Suid-Afrika in 1994, tesame met die promulgering van 'n nuwe Grondwet in 1996, het sekere nuwe vorme van ontwrigting in die onderwys meegebring. Die onderwys in die land word sedertdien op groot skaal en diepgaande getransformeer. Die transformasie het alle aspekte van die onderwys getref - vanaf die leerdersamestelling van skole tot die hervorming van die kurrikulum (Anon., 2001:2). Die hervorming van die kurrikulum was byvoorbeeld so ingrypend dat baie onderwysers, leerders, ouers en selfs onderwyskundiges dit vreemd, ingewikkeld en onverstaanbaar gevind het. Dit het onder meer die hersiening van die kurrikulum genoodsaak (vgl. die publikasie van die Hersiene Nasionale Kurrikulum in Julie 2001). 
Die insluiting van 'n Handves van Menseregte in die Grondwet (SA, 1996b) het 'n nuwe benadering tot die verhoudinge tussen die inwoners van die land meegebring. So ingrypend is die veranderinge wat in die Suid-Afrikaanse samelewing, en daarmee saam, die onderwys aangebring is, dat die destydse Minister van Onderwys so onlangs as in 1998 nog kon sê dat die transformasie in die onderwys moes voortgaan (Bengu, 1998).

Soos in 'n aparte afdeling van hierdie artikel aangedui sal word, word die bedeling na 1994 in die Suid-Afrikaanse onderwys deur onstabiliteit en veranderinge op verskillende terreine gekenmerk. Hierdie ontwrigting en onstabiliteit bring nog steeds in 'n mindere of meerdere mate 'n belewing van ongeborgenheid (Engels: "insecurity") by baie onderwysers teweeg.

Die doel van hierdie artikel is om, teen die agtergrond van 'n filosofiespedagogiese verwysingsraamwerk, aan te toon wat die uitwerking van die ontwrigting en onstabiliteit in die onderwys op die geborgenheidsbelewenis van die onderwyser is, en om daarna riglyne voor te stel aan die hand waarvan die onderwyser groter geborgenheid, stabiliteit en veiligheid in die onderwys sal kan ondervind. Die riglyne beliggaam die voorwaardes vir die realisering van 'n geborgenheidsruimte vir die onderwyser, wat hom of haar in staat sal stel tot opvoedende onderwys.

\section{Filosofies-pedagogiese raamwerk}

In hierdie afdeling word gepoog om 'n filosofies-pedagogiese raamwerk waarbinne die probleem van ongeborgenheid in die onderwyssituasie geakkommodeer kan word te belig. Die mens is as die kroon van God se skepping in die wêreld geplaas (vgl. Ps. 8 wat hierdie besondere posisie van die mens belig). Dit beteken dat die mens nie slegs moet heers oor die skepping nie, maar dit ook moet ontwikkel en tot verdere ontplooiing moet bring. God het volmaak geskep, maar nie volledig nie. Die mens is sy mandaathouer, sy rentmeester in die skepping (Middleton \& Walsh, 1995:154, 157). Hy is deur God in die skepping geplaas en tot die taak geroep om die skepping tot ontplooiing te bring. Om dit doeltreffend te kan doen, moet die mens God se wil vir die skepping navors (soos waarneembaar uit die gedrag van die geskape dinge, maar ook in die Skrifgeworde Woord van God - die Bybel). Hy moet hierdie wetmatighede, wat in sommige stadia van die mens se handelinge en ervarings van die werklikheid chaoties kan voorkom, verstaan en benut ten einde die skepping te kan ontwikkel (Klapwijk, 1987:186; Fowler, 1991:27-29).

Die kultuurtaak van die mens, wat aanvanklik voor die hand liggend gelyk het, word ernstig in die wiele gery deur die teenwoordigheid van die sonde in die werklikheid. Die sonde bring ontwrigting, stryd, rusie, 
wanorde en gebroke verhoudings in die skepping mee. Dit het ook ontwrigting in die onderwys meegebring. Die mens beleef as gevolg daarvan dikwels ongeborgenheid en onveiligheid. Waar die ontplooiing van die skepping in sigself soms tot onsekerheid lei, is die situasie in die tydperk na die sondeval aansienlik gekompliseer. Verandering, hervorming en transformasie word derhalwe gekenmerk deur die volgende tipe groepe: mense wat te vinnig probeer vorder en verander, ander wat stappe neem en maatreëls probeer instel wat nie goed deurdink is nie, ander wat probeer sloer, rem en walgooi. Daar is egter ook ander wat die hervormingspogings probeer kelder en dwarsboom, ander wat apaties raak en hulle onttrek (as 't ware psigologies agterbly in die "goeie ou dae" toe dinge nog "sus of so" was), ander wat die veranderinge probeer ontsnap deur te emigreer, en vele meer. Die veranderinge of ontplooiing in die skepping word nie meer gekenmerk deur die harmonie van die kultuurbeoefening voor die sondeval nie (bv. in die naamgewing van die diere en ander dinge en die bewerking van die grond).

Ten spyte van hierdie ontwrigting is die mens steeds beeld van God, sy mandaathouer en rentmeester in die skepping. Die mens staan steeds in 'n verhouding met God, hetsy 'n verhouding waarin God met oorgawe geëer en gedien word, of een waarin die mens afvallig geraak het. Die mens bly nog mens: 'n verhoudingswese (met God, medemens, die skepping en die self), 'n geroepe wese, toegerus met die vaardighede wat nodig is om die skepping verder te ontwikkel. Die mens is nog steeds toegerus met skeppende vaardighede; kreatiewe denke sorg vir nuwe moontlikhede en ontwikkelinge. Die mens het steeds 'n inherente sin vir verantwoordelikheid (aan God of 'n surrogaat-god) en toerekenbaarheid ("accountability").

Die feit dat die mens mens gebly het ten spyte van die ontwrigtende werking van die sonde is die waarborg vir historiese kontinuïteit in die skepping: daar is steeds voortgang in die skepping, al volg dit soms 'n kronkelgang (Van Woudenberg, 1992:92).

Antropologies bekyk, is die persepsie (gevoel, ervaring, gewaarwording) van geborgenheid (veiligheid, stabiliteit, sekerheid, sekuriteit) 'n psigologies-etiese verskynsel (vgl. Van Woudenberg, 1992:85, 109). Dit is 'n ingeskape eienskap van die mens om te soek na veiligheid, sekerheid, voorspelbaarheid, stabiliteit, kortom: geborgenheid. Dit is eweneens ingeskape by die mens om gevoelens oor die mate van geborgenheid wat ervaar word te hê. Geborgenheid kan as 'n etiese verskynsel beskou word aangesien dit te doen het met verhoudings. 'n Persoon is byvoorbeeld geborge in sy of haar religieuse verhouding met God. 'n Mens ervaar ook geborgenheid in die verhouding met ander mense (byvoorbeeld ' $n$ leerder in die teenwoordigheid en onder die bemoeienis van 'n 
bekwame onderwyser). Jy kan ook geborge voel in die politiek-staatkundige omstandighede wat die owerheid (wat uit mense bestaan) tot stand bring. Geborgenheid kan ook ervaar word deur wat lewelose dinge in die skepping aan 'n mens bied (soos die veiligheid wat hoë heinings rondom die huis bied, of wat baie geld in die bank kan gee).

Die onderwys is een van die kontekste waarin die deelnemers geborgenheid of ongeborgenheid kan ervaar. Die onderwyser ervaar byvoorbeeld geborgenheid in die onderwys in die volgende omstandighede:

- As hy of sy 'n vaste aanstelling het, met voldoende vergoeding sodat alle verpligtinge sonder kommer nagekom kan word.

- As hy of sy volledig deur die ander personeel, die ouers, die leerders en die gemeenskap aanvaar word.

- As die politiek-staatkundige bedeling 'n stabiele onderwysstelsel met voorspelbare en konstante eienskappe bied.

- As duidelike prestasie- en gedragsriglyne gebied word. Onsekerheid oor wat gedoen moet word, word daardeur uit die weg geruim.

- As hy of sy relatief selfstandig as professionele persoon kan optree, en nie gedurig oor die skouer hoef te kyk na wat ouers, ander onderwysers, die skoolhoof, die gemeenskap, superintendente, ensovoorts dink of sê nie.

- As hy of sy die ondersteuning van die skool se beheerliggaam en die skoolhoof ontvang, en daar by die onderwyser nie kommer oor moontlike dislojaliteit hoef te wees nie.

- As hy of sy die organisasieklimaat in die skool as positief ervaar.

- As hy of sy ondersteuning en lojaliteit van kollegas ervaar.

- As hy of sy as professionele persoon die regte klaskamerklimaat kan skep, en die omstandighede bevorderlik is vir doeltreffende onderrig en leer - en opvoeding.

- As hy voel dat daar orde, dissipline, harmonie, wedersydse respek, 'n veilige opvoedende onderwysomgewing is.

Weens die kompleksiteit van die onderwys kan alle omstandighede waarin geborgenheid deur die onderwyser ervaar word, nie hier genoem word nie. In die lig van die voorgaande argumentasielyn is dit egter duidelik dat sinvolle skoolonderwys nie kan plaasvind indien die onderwyser nie geborge voel nie. Die woord "geborgenheid" het naamlik die woord "bêre" as kern. "Geborgen" is die verlede deelwoord van die Nederlandse "bergen". Oorspronklik is 'n skip met sy bemanning en vrag 
"geberg", dit wil sê in veiligheid gebring, na 'n veilige ruimte gebring en daar bewaar. In oordragtelike sin beteken geborgenheid iets soos om iemand veilig te maak, te koester, veilig weg te sit, te beskerm. Die Engels daarvoor is: "provided for, freedom from care". Etimologies is die woord "bêre" (Nederlands: "bergen") verwant aan woorde soos "burg, borg en herberg". Al hierdie woorde besit die konnotasie van stewigheid, beskutting, veiligheid en sekerheid.

As daar kommer in die onderwyser se gemoed is oor die gebrek aan fisiese of psigologiese geborgenheid of veiligheid, kan daar nie sprake wees van algehele toewyding aan die onderwystaak nie. 'n Ongeborge onderwyser se gedagtes is dikwels elders of hy is psigies sodanig verkreupel dat hy nie die opvoedende onderwystaak kan verrig nie.

Onderwys as sodanig is voorts ook nie vanselfsprekend pedagogies en opvoedend van aard nie, dit wil sê uitdruklik gerig op die toerusting van die leerders om as toekomstige volwassenes hulle mandaat as rentmeesters van God te kan nakom nie. 'n Onderwyser wat ongeborgenheid in 'n skool of klaskamer ervaar, kan bloot meganies-oppervlakkig toespits op die handelinge wat nodig is om die leerders deur die betrokke graad te kry of te forseer, maar daar is nie die pedagogiese toewyding of gemotiveerdheid wat so kenmerkend is van 'n onderwyser wat geborgenheid ervaar nie. 'n Onderwyser wat ongeborge voel, sal hom- of haarself nie pertinent daaraan toewy om pedagogiese, dit wil sê ware opvoedende, bemoeienis met elke leerder te maak nie, en om sodoende van elke leerder inderdaad 'n opvoedeling te maak nie. Prestasie soos in syfers uitgedruk, is dan al wat saak maak; die breër pedagogiese toerusting wat die jongmense nodig het vir die nakoming van hulle toekomstige roeping, sal agterweë gelaat word. Kortom: die pedagogiese toewyding of "commitment" wat duidelik te bespeur is by 'n gemotiveerde, geborge en betroubare onderwyser sal nie na vore (kan) kom nie.

Sommige van die voorbeelde van onderwysergedrag wat in die volgende afdeling vermeld word, is juis kensketsend van hierdie gebrek aan pedagogiese toewyding of "commitment", en dit is weer simptomaties van die ongeborgenheid van die onderwyser.

\section{Oorsake van ongeborgenheid by onderwysers in die Suid-Afrikaanse onderwysbedeling na 1994}

\subsection{Nuwe Grondwet en Handves van Fundamentele Regte}

Soos 'n mens kan verwag, het die politiek-staatkundige hervormings in Suid-Afrika sedert 1994 onsekerheid by baie van die land se inwoners meegebring. Die land het een van die mees progressiewe grondwette ter 
wêreld gekry. Die Grondwet (SA, 1996b) het nie slegs die vorige staatkundige bedeling tersyde gestel nie, maar het ook, weens die nadruk op menseregte daarin en die feit dat 'n regstaat tot stand gekom het, heeltemal nuwe verhoudings tussen Suid-Afrikaners onderling maar ook teenoor die staat en byvoorbeeld werkgewers meegebring. Hoewel dit dus enersyds ontwrigtend gewerk het deur 'n vorige (in sigself onstabiele) bedeling tot ' $n$ einde te bring, het dit 'n mate van rus gebring deurdat die verhoudings in die land en die fundamentele regte van mense opnuut en duideliker gedefinieer is. Ten spyte van die rus wat dit gebring het, het dit ook onsekerheid in die hand gewerk, in die sin dat verhoudings anders gedefinieer is, en onderwysers eers daarmee vertroud moes raak. Die transformasie van byvoorbeeld werkgewer-werknemersverhoudings en die reg van toegang tot inligting het, minstens aanvanklik, onsekerheid meegebring.

\subsection{Negatiewe gevoelens by onderwysers}

In 'n ondersoek wat in 1999 landswyd gedoen is onder sowat 1500 onderwysers (Mentz, 1999), is gevind dat die respondente oor die algemeen nie positiewe persepsies oor die onderwysbedeling na 1994 ervaar het nie. In die histories minder goed bedeelde skole, veral, is gevind dat onderwysers ongeborgenheid ervaar het omdat hulle nie genoegsame ondersteuning van hulle skoolhoofde ontvang het nie. Die faktor "Ondersteunende gedrag van die skoolhoof" het 'n gestandaardiseerde telling van 332 behaal (Mentz, 1999:49). 'n Gemiddelde telling is 500 , wat beteken dat die telling van 332 vir hierdie faktor as baie laag geklassifiseer word. As gevolg hiervan ervaar onderwysers 'n groter mate van onverbondenheid met die skoolsituasie en derhalwe groter frustrasie. Vir die faktor "Gefrustreerde gedrag van die onderwysers" is 'n telling van 446 in histories minder goed bedeelde skole behaal, wat 'n klassifikasie van laag beteken (Mentz, 1999:51). Naastenby dieselfde tellings is egter ook behaal in histories bevoordeelde skole, wat beteken dat die probleem van frustrasie onder onderwysers nie beperk is tot histories benadeelde skole nie. Deur middel van ' $n$ variansie-analise en die bepaling van die effekgrootte van die verskille (d-waarde) is gevind dat daar nie 'n statisties betekenisvolle verskil tussen die belewing van frustrasie van onderwysers in bevoordeelde en benadeelde skole bestaan nie.

\subsection{Inmenging op professionele terrein van onderwyser}

Hierbenewens beleef onderwysers ook gevoelens van ongeborgenheid weens die inmenging van hulle skole se beheerliggame op die professsionele terrein van die skool en die onderwyser (vgl. Anon., 1999c:14). Druk word soms op die onderwyser uitgeoefen om veranderinge wat 
deur die onderwysdepartement ingevoer word, teen te staan en nie te implementeer nie. Hierdie toedrag van sake veroorsaak dat die onderwyser (in sommige gevalle 'n skoolhoof) ongeborgenheid ervaar; hy of sy word fyngemaal tussen die beheerliggaam aan die een kant, en die onderwysdepartement aan die ander kant. Dit gebeur dat onderwysers swig onder die druk (vgl. die selfmoord van 'n Pretoriase skoolhoof Rademeyer \& Erasmus, 1999:15). In 'n ander geval is die skoolhoof van onprofessionele gedrag beskuldig, onder meer omdat hy 'n gebed in die personeelkamer gedoen het (Rademeyer \& Erasmus, 1999:5).

\subsection{Onprofessionele gedrag van kollegas}

Die onprofessionele gedrag en optrede van kollegas kan 'n onderwyser verder ook moedeloos maak en ongeborge laat voel. Professionele gedrag word onder meer gekenmerk deur 'n ingesteldheid van diensbaarheid (Oosthuizen, 1998:93), sanksionering deur die gemeenskap, gespesialiseerdheid van die deskundigheidsterrein, volgehoue navorsing en die nakoming van 'n etiese kode (vgl. Loots, 1992:17). Daar is weinig blyke van die nakoming van hierdie eienskappe van professionaliteit in gevalle waar onderwysers laat kom vir skool, nie in klaskamers teenwoordig is as die leerders onderrig moet ontvang nie, en hulle selfs by misdaad betrokke is (Anon., 1999a:10). In 'n oudit wat in die Noordwesprovinsie gedoen is, is bevind dat die swak matrikulasieuitslae van die leerders toegeskryf kan word aan die onprofessionele gedrag van sommige onderwysers. Hulle is nie slegs ontoereikend vir hulle taak gekwalifiseer nie, maar daag ook nie vir hulle klasse op nie (Du Preez, 1999:12). Daardeur laat hulle nie slegs die leerders in die steek nie, maar bring die hele professie in diskrediet (Erasmus, 1999:9; Bezuidenhout, 1999:2).

Hierdie soort gedrag kring uit tot ander optredes wat nadelig is vir die onderwys in die skole. Op 24 Augustus 1999 het na raming ongeveer een miljoen leerders saam met hulle onderwysers deelgeneem aan die eerste onderwysstaking in Suid-Afrika. In die proses is eiendom in die strate verniel en is chaos gesaai (Steenkamp, 1999:2).

In uiterste gevalle laat die onprofessionele optrede van kollegas onderwysers selfs vir hulle lewens vrees. Die weerspannigheid van onderwysers het een skoolhoof sodanig ontwrig dat sy nie haar werk kon doen nie, en vir haar eie veiligheid begin vrees het (Ntombela, 1999:6). Haar personeellede daag dikwels nie by die skool op nie - sonder enige verskoning. Nog 'n simptoom van onprofessionele gedrag is die neiging om die blaam vir swak prestasie op kollegas, die departement of iets of iemand anders te plaas, en geen eie verantwoordelikheid te neem nie. Van der Westhuizen et al. (1999:318) het in 'n ondersoek na die swak 
matriekuitslae in 1997 bevind dat onderwysers en leerlinge die onderwysdepartement en skoolhoof blameer vir die swak uitslae, en nie hulleself nie.

Wat die prentjie nog verder verdonker, is die feit dat die onderwysers verbonde aan sommige skole weier dat superintendente op die skoolterreine kom, en dat daar dus nie ondersoek ingestel kan word na die toestande aldaar nie (Ntombela, 1999:6).

\subsection{Ontoereikende toerusting vir die taak}

Soos reeds gemeld, is baie onderwysers nie goed genoeg toegerus vir die taak wat van hulle verwag word om in die skole na te kom nie (vgl. Du Preez, 1999:12). Wat Wiskunde- en Wetenskaponderrig betref, is sommige onderwysers skaars beter as die leerders toegerus (Taylor \& Vinjevold, 1999:141). Hulle konseptuele vaardighede en toerusting in die vakke is sodanig onvoldoende dat hulle nie kan bydra tot goeie leeruitkomste by die leerders nie (Taylor \& Vinjevold, 1999:230). Hulle leesen skryfvaardighede is ook nie na wense nie, en daar is onsekerheid by die onderwysers of lees een van die vaardighede is wat die leerders moet bemeester (Taylor \& Vinjevold, 1999:231). Die ontoereikende toerusting van die onderwysers vir hulle taak is inderdaad 'n probleem in die onderwys, een wat onvermydelik tot onsekerheid en gevoelens van ongeborgenheid by die onderwyser lei.

\subsection{Dalende aansien van die professie by die publiek}

Onder meer weens hierdie optrede en gedrag van onderwysers en die algemene toestande in die skole het die onderwys as professie in aansien gedaal by die algemene publiek (Anon., 1999b:1). Die aansien van onderwysers het inderdaad 'n laagtepunt bereik, en daar is al in sommige kringe gewonder of onderwysers die salarissse wat hulle betaal word, waardig is. Hierdie beeld van die onderwys in die omliggende gemeenskap dra verder by tot gevoelens van ontoereikendheid, en daarmee van ongeborgenheid.

\section{Riglyne om die geborgenheidsgevoel van onderwysers te versterk}

Deur die geborgenheidsgevoel van onderwysers te versterk, kan verseker word dat opvoedende onderwys in skole kan plaasvind. Die uiteensetting in die vorige afdeling het nie ten doel om aan te toon dat onderwysers in Suid-Afrika sedert 1994 meer ongeborge voel as ooit voorheen nie. Omdat hierdie tydsgewrig egter histories so na aan ons staan, dien dit as illustrasie van die feit dat, as die onderwyser on- 
geborgenheid in sy of haar omstandighede ervaar, daar nie juis sprake van opvoedende onderwys in die betrokke klaskamers of skole kan wees nie. Die leerders wat tans aan sommige onderwysers blootgestel is, en die feit dat die onderwysers beduidende gevoelens van ongeborgenheid in hulle besondere omstandighede ervaar, loop ernstige risiko's om te faal en om nie toereikend vir die toekoms voorberei (opgevoed) te word nie. Soos onderwysowerhede in alle ander tydsgewrigte, sal die nasionale en provinsiale onderwysowerhede van Suid-Afrika aan die begin van die 21 ste eeu ernstige aandag moet gee aan die versterking van die geborgenheidsgevoelens van onderwysers. In dié proses kan die volgende riglyne gevolg word:

\subsection{Die behoud van perspektief}

Dit is in die eerste instansie noodsaaklik dat alle betrokkenes by die onderwys, en dit sluit veral ook onderwysers in, onder die besef sal kom (of gebring word) dat elke periode van die mensdom se geskiedenis, ook sy onderwysgeskiedenis, ontwrigtend (kan) inwerk op die mens se gees sowel as op sy konkrete lewensomstandighede. Onderwysers, veral, moet besef dat die bedeling na 1994 in die onderwys nie noodwendig meer ontwrigtend en onstabiel is as wat enige ander periode in die land se geskiedenis was nie. Dit weeg byvoorbeeld waarskynlik nog nie op teen die ontwrigting wat die swart volkere in die onderwys beleef het tydens hulle Groot Trek uit die sentraal-weste van Afrika (0-1600 n.C.) of die Difaqane (1816-1820) nie. Dit kan ook nie vergelyk word met die ontwrigting wat die Britse setlaars (1820 en daarna) in die Oos-Kaap beleef het nie. Dit kan ook nie vergelyk word met die probleme wat die Voortrekkers (1836 en daarna) ten aansien van die onderwys ondervind het nie, en ook nie met die onderwystoestande tydens byvoorbeeld die Tweede Anglo-Boereoorlog (1899-1902) of die Milner-regìme (1902 en daarna) nie. Ook nie met die ontwrigting in die periode 1976-1994 nie. Sulke voorbeelde uit die onderwysgeskiedenis kan vermenigvuldig word.

Die eerste riglyn is dus dat onderwysers perspektief moet behou ten einde gevoelens van geborgenheid in hulle eie moeilike omstandighede te kan beleef.

\subsection{Insig in die historiese kontinuïteitsbeginsel}

Dit is in die tweede instansie noodsaaklik dat onderwysers insig in die beginsel van historiese kontinuïteit sal verkry. Wat in 1994 in Suid-Afrika gebeur het, was 'n direkte uitvloeisel van gebeure wat direk daaraan voorafgegaan het, maar ook gebeure wat verder terug in die verlede lê. Die jaar 1994 is wel 'n waterskeidingsjaar in die Suid-Afrikaanse geskiedenis, maar dit verteenwoordig nie historiese diskontinuït ('n 
rewolusie) nie. Die jaar 1994 verteenwoordig progressie in die land se geskiedenis. 'n Onderwyser wat met hierdie insig leef en werk, behou moed en beur vorentoe.

\subsection{Locus van kontrole}

Elke onderwyser kan self 'n bydrae maak tot die eie belewing van geborgenheidsgevoelens. Onderwysers moet die locus van kontrole in hulleself soek, en nie ander vir hulle gevoelens van onbehaaglikheid en ongeborgenheid blameer nie. Sodra 'n onderwyser die locus van kontrole in die self vind, kom daar groter verantwoordelikheid, aanspreeklikheid en toerekenbaarheid, en verdwyn die neiging om ander te blameer of agter hulle foute weg te kruip.

\subsection{Rentmeesterskap}

Dit is in die vierde instansie noodsaaklik dat onderwysers sal verstaan dat die pedagogiese bemoeienis van leerders afhanklik is van die mate waarin die onderwyser sy of haar geroepenheid as rentmeester en mandaathouer van God in die skepping beleef. Hierdie rentmeesterskap moet ook beleef word ten aansien van die leerder. Onderwysers moet dit as hulle Godgegewe taak en roeping beskou om leerders as opvoedelinge te beskou, om van die onderwys 'n opvoedingsgeleentheid te maak, om opvoedende onderwys aan die leerders te gee. Om hierdie geroepenheid tot rentmeesterskap te kan ervaar behoort nie direk proporsioneel tot die mate van geborgenheid te staan nie - soos wat dikwels in die praktyk die geval is. ' $n$ Onderwyser wat in die regte religieuse verhouding tot God staan, kan sy of haar geroepenheid juis voel in die mees ongunstige (Engels: "adverse") omstandighede. Die dryfkrag van die Goddelike roeping (die Vocatio Dei) is so sterk dat dit die self en ander rondom 'n mens uit die moeras van moedeloosheid, frustrasie en ongeborgenheid kan trek.

\subsection{Pedagogiese insig}

Die volgende riglyn is om onderwysers aan te spoor tot 'n meer diepgaande studie van die pedagogiese handeling. Dit is ' $n$ gegewe, soos hierbo aangetoon, dat sommige van die onderwysers in Suid-Afrika nog nie eens hulle eie spesialisvak of -leerarea behoorlik beheers nie. Nie slegs die spesialisgebied moet egter ten volle beheers word nie, maar ook die pedagogiese gebied. Die waarlik geroepe onderwyser sal weet dat die pedagogiese verhouding met die leerder bemoeienis met die opvoedeling impliseer. Hierdie bemoeienis kan die volgende fasette insluit: leiding, toerusting, vertroueskepping, strukturering, instaatstelling, ontplooiing en dissipelskap (Van Brummelen, 1988: 28 e.v.). Dit is die 
verantwoordelikheid van die onderwysers se opleiers en werkgewers om sodanige pedagogiese insig by die onderwysers tuis te bring.

\subsection{Insig in die betekenis van geborgenheid}

Verder is dit nodig om onderwysers deur sowel voordiens- as indiensopleiding toe te rus met 'n meta-perspektief op wat geborgenheid alles inhou. Saam met sy of haar kollegas moet 'n onderwyser op 'n afstand kan gaan staan en hom- of haarself afvra wat geborgenheid werklik behels, ook vir elkeen afsonderlik in die besondere situasie. Gesamentlik en individueel moet hulle vra wat hulle veilig(er) en (meer) beskermd sal laat voel, en dan moet hulle direk daarna streef om hierdie voorwaardes tot 'n werklikheid vir hulleself te maak. Die volgende is praktiese voorbeelde. As die onderwysers tydens 'n dinkskrum vasstel dat hulle nie voldoende ondersteuning van die beheerliggaam en die skoolhoof ontvang nie, moet hulle besluit om werk daarvan te maak. 'n Ontmoeting met die voorsitter van die beheerliggaam en die skoolhoof deur een of twee onderwyser-afgevaardigdes moet dan plaasvind en die saak onder vier oë uitmaak.

Daarteenoor: die skoolhoof, na wie in die bespreking hierbo verwys is, wat na haar oordeel nie ondersteuning van haar personeel ontvang nie, moet ook werk maak daarvan. Sy moet die onderwysers ontmoet en haar gevoelens van ongeborgenheid deur hulle dade en optrede met hulle bespreek. As dit nie daartoe lei dat hulle gedrag in die skool en teenoor haar verbeter nie, moet daar dissiplinêr teenoor hulle opgetree word. Daar bestaan onderwysregtelike instrumente, soos amptelike grieweprosedures, om sodanige stappe teen onderwysers te kan neem.

\subsection{Kringsoewereiniteit en -universaliteit}

Nog 'n riglyn wat gevolg kan word, is dat onderwysers toegerus behoort te word om die werking van kringsoewereiniteit te verstaan. Hoewel hierdie ' $n$ taamlik ingewikkelde samelewingsverbandelike riglyn is, kan dit in die breë by onderwysers tuisgebring word tydens voor- en indiensopleiding. Die inmenging in die professionele sfeer van die onderwyser deur die beheerliggaam, ouers, kerke of die breë gemeenskap kan afneem namate insig in die beginsel van kringsoewereiniteit by al die betrokkenes toeneem. Daarmee saam kan kollegialiteit onder onderwysers onderling toeneem, en samewerking met die skoolhoof, die staat, die kerke, die onderwysdepartement, die samelewing, die ouers en alle ander rolspelers, as onderwysers se insig in die teenhanger van kringsoewereiniteit toeneem, te wete kringuniversaliteit. Juis die pedagogiese inslag van die onderwys neem in betekenis, omvattendheid en gehalte toe as die onderwyser besef dat al hierdie rolspelers in die onderwys 
maar net besorg is oor die toerusting van een en dieselfde leerder. Juis dan werk almal as pedagogiese span saam en is daar minder kommer oor moontlike grensoorskrydings tussen die verskillende partye betrokke by die onderwys. Hierdie besef werk geborgenheid in die hand.

Deur die verweefde toepassing van die riglyne van kringsoewereiniteit en kringuniversaliteit kan daadwerklik uitdrukking gegee word aan die bepalings van die Suid-Afrikaanse Skolewet (Suid-Afrika, 1996a) wat heelwat bevoegdhede aan die plaaslike gemeenskappe oorgedra het. Dit sal die beheerliggame ook in staat stel om hulle te verweer teen die neiging tot sentralisering deur die provinsiale en nasionale onderwysowerhede. Dit sal verhoed dat politieke gesagsdraers op onderwysterrein oortree, en dit sal ook die gesag afwentel na die vlakke waar dit ten beste uitgevoer kan word. Die skorsing van leerders is ' $n$ voorbeeld hiervan. Die Grondwet (SA, 1996b artikels 1 en 7); die Suid-Afrikaanse Skolewet (Suid-Afrika, 1996a artikel 4(a)(iii)), die Wet op Nasionale Onderwysbeleid (Suid-Afrika, 1996c artikel 4(m)) en die SA Skolewet SA (Suid-Afrika, 1996d, artikel 16(1)) maak reeds voorsiening vir die afwenteling van gesag en bevoegdheid in hierdie verband. Die belangrikste voorwaarde hierby is dat geborgenheid (met veiligheid en versorging as die betekeniskern daarvan) eerder as vergelding, soos gebruiklik in die regswetenskappe, as die sinkern van onderwysregtelike prosedures en handelinge beskou moet word. Hierdie verskuiwing hang saam met die pedagogiese aard van die geborgenheidsruimte wat die onderwyser behoort te ervaar in die professie (Malherbe, 1995:2).

\subsection{Professionele onderwysergedrag}

Die professionaliteit van onderwysers moet verhoog word. Weens die groot getal histories benadeelde skole wat daar tans in die stelsel is, is hierdie inderdaad een van die ernstigste probleme waarmee die onderwysowerhede te kampe het. Dit is nie moontlik om al die oorsake vir onprofessionele gedrag hier te noem nie, maar dit is duidelik dat 'n gebrek aan geborgenheidsgevoel een van die oorsake is. Onderwysers kom laat by die skool of daag glad nie op nie omdat hulle nie daar psigologies en selfs fisies "veilig" voel nie. Die opskrif van 'n onlangse koerantartikel (Grey, 2001:1) is veelseggend: "Scared educators get paid for doing nothing". Die inhoud van die artikel skets die omvang van hierdie probleem. Oppelt (2001) verwys na 'n soortgelyke situasie:

Sometimes it appears as if some pupils and teachers have no clue why they are there. The Education MEC visited Thesele High in Soweto, and found schooling was the last thing on the minds of staff and pupils. He found a boy with a bottle of brandy and teachers unprepared to teach. 
Die eise van die onderwysdepartement, die beheerliggaam en die skoolhoof is oorweldigend. Kurrikulum 2005 in sy aanvanklike vorm was so ingewikkeld en intimiderend dat selfs die bes opgeleide onderwysers soms weinig sin daarvan kon maak (vgl. die studiehulp wat NAPOSA nog in Augustus 2001 aan onderwysers beskikbaar moes stel met die oog op die hantering van die komende Nasionale Seniorsertifikaat-eksamen wat deur leerders én onderwysers as spanningsvol ervaar is; vgl. ook Ricci, 2001:20). Swakker opgeleide onderwysers het gewoon op die vlug geslaan, psigologies of met die voete. Die publikasie van die hersiene weergawe daarvan in Julie 2001 moet derhalwe verwelkom word. Groot klasse van tot 70 of meer leerlinge werk ook intimiderend in op die gemoed van die onderwyser.

Hierdie riglyn kom, kortom, daarop neer dat die professionaliteit van die onderwyser nie vanself sal verhoog nie. Dit sal ook nie help om die simptome daarvan te probeer genees nie. Die oorsake van die probleem sal radikaal nagegaan moet word en daarna reggestel moet word. Een van die maniere is om die gedragskode van onderwysers soos opgestel deur die Suid-Afrikaanse Raad vir Opvoeders strenger toe te pas, onder meer deur die desentralisasie van die Raad se bevoegdhede tot op distriksvlak. Deur dit te doen kan die Raad beter waghou oor onderwysergedrag en kan daar ook deurgedring word tot die wortels van die probleem. Die bevoegdhede van die Raad kan vir hierdie doel gedelegeer word na bevoegde distriksbestuurders met opleiding in die onderwysreg. Hulle kan prima facie-sake aanhoor, en indien nodig, ligte vonnisse vel of regstellende stappe neem. Hierbenewens kan die bevoegdhede van die Raad self uitgebrei word om swaarder vonnisse te kan oplê as tans. Onwettige stakings deur onderwysers kan onder meer langs hierdie weg voorkom word. Kortom: die oorsake van onprofessionele gedrag moet vas- en reggestel word; dit help nie om die simptome van ongeborgenheid te probeer genees nie.

\subsection{Onderwysers as opvoedende onderwysspesialiste}

Onderwysers moet deur middel van voor- en indiensopleiding toegerus word as vak- of leerareaspesialiste, en daarmee saam toegerus word om die pedagogiese betekenis van die beoefening van hulle professie in die skool te verstaan. Hulle moet verstaan wat dit beteken om leerinhoude so te hanteer dat dit pedagogiese betekenis kry, dat die leerders ook opvoedelinge kan word (vgl. 4.5).

\subsection{Bydraes deur die ouers en die gemeenskap}

'n Volgende aspek het te doen met die openbare mening oor die onderwys. Dit is juis een van die onrusbarendste aspekte van uitsprake 
oor die onderwys vandag dat daar baie oor die onprofessionaliteit van onderwysers gepraat word, maar dat die saak nie radikaal aangepak en reggestel word nie. Waar die lands- en onderwysowerhede nie oor genoegsame middele beskik om die onderwys op te hef, en sodoende by te dra tot die geborgenheid van die onderwyser nie, is dit belangrik dat die algemene publiek nog meer sal ingryp. Bo en behalwe belasting en skoolgeld wat reeds betaal word, moet daar nog ander bydraes gemaak word. Kortom: die kritiek op die onderwys moet plek maak vir daadwerklike, regstellende ingrype en optrede. Tempelhoff (1999:4) het egter waargeneem dat daar, ten spyte van die noodsaaklikheid van ingrype en deelname, 'n apatiese houding by ouers jeens die onderwys te bespeur is. Ouers doen nog nie genoeg om die plaaslike skool tot finansiële en professionele selfstandigheid op te hef nie. As gevolg daarvan kan baie skole nog nie hulle rol vervul as sentra van kundigheid en kennis in gemeenskappe nie.

\subsection{Aanpassing by nuwe kulturele omstandighede}

Dit is nodig dat onderwysers sal aanpas by die nuwe kultuur van fundamentele regte (vgl. die aanhef tot die Wet op Nasionale Onderwysbeleid - Suid-Afrika, 1996c). Die Handves van Fundamentele Regte bied in beginsel aan die onderwyser 'n geborgenheidsruimte. Elke onderwyser moet die omvang en beperkinge van hierdie ruimte verstaan. Om dit te kan doen is dit nodig dat elke onderwyser voor- en indiensopleiding in die onderwysreg moet ondergaan (vgl. Joubert, 1889: 210, wat aangetoon het dat daar nog ernstige opleidingsleemtes in hierdie verband bestaan).

\section{Gevolgtrekking en samevatting}

Die algemene en die onderwyswetgewing wat sedert 1994 in Suid-Afrika gepromulgeer is, bied in beginsel 'n geborgenheidsruimte aan die onderwyser. Hoewel die nuwe bedeling deur sommige onderwysers as ontwrigtend en herbergloos ervaar word, besit dit die potensiaal om aan elke goed gekwalifiseerde onderwyser 'n veilige bestaans- en werksruimte te voorsien. Weens die erfenis van die verlede is daar onderwysers wat nog nie tot hierdie insig gekom het nie, en as 't ware psigologies verlate en ongeborge voel. Hulle voel so weens die teenwoordigheid van (nuwe) intimiderende omstandighede in die onderwys. Weens allerlei agterstande in die onderwys is hulle ook nie in staat om te besef dat hulle locus van kontrole intern behoort te wees nie, en poog nog om die oorsaak van die ongeborgenheid wat hulle ervaar, buite hulleself te soek. Die toepassing van die riglyne wat hierbo aangebied is, sal onderwysers nie slegs die locus van kontrole tot binne hulleself kan laat verskuif nie, maar sal hulle ook meer geborgenheid laat ervaar. 
Saam met 'n verhoogde gevoel van geborgenheid in die onderwys sal die insig toenemend by onderwysers deurbreek dat hulle onderwysbemoeienis met die leerders inderdaad ook pedagogies van aard behoort te wees. Soos aangedui, sal dit egter 'n grootskeepse gesamentlike poging van alle rolspelers by die onderwys verg om al die onderwysers in die land tot 'n groter geborgenheidsbelewenis te bring.

Onderwysers, veral diegene wat hulle professie beoefen vanuit die riglyne wat die Skrif hulle bied, behoort nie terug te deins vir die probleem van ongeborgenheid nie. In alle vorme van werk, en in elke tydsgewrig, is daar omstandighede wat ongeborgenheid in die hand kan werk. Hierdie perspektief, tesame met die besef dat om te werk - in hierdie geval onderwys te gee - 'n respons van die mens op God se roeping is, stel die onderwyser in staat om selfs in die mees ongunstige omstandighede moed te hou, en die toewyding aan die dag te lê wat benodig word om welslae te behaal. Om onderwys te gee is een van die mees betekenisvolle vorme van rentmeesterskap in diens van God: die onderwys is een van weinig beroepe waar daar met die kinders en die jeug gewerk word, en waar 'n bydrae gemaak kan word tot die groei tot volwassenheid van die jongmense, en gevolglik tot die voordeel van die land en die nasie. Deur hierdie roeping toegewyd en nougeset na te kom, dien die onderwyser ook vir God, wat haar nie slegs tot die taak geroep het nie, maar haar ook die talente, kragte en die middele daartoe gee.

Samevattend dus: die geborgenheidsbelewing van die Bybelgelowige onderwyser is ' $n$ kernvoorwaarde vir die opvoedende onderwys van die opkomende geslag.

\section{Bibliografie}

ANON. 1999a. Gee dit tande. Beeld: 10, Maart 30.

ANON. 1999b. Asmal val onderwysvakbond skerp aan by kongres. Beeld: 1, Sept. 27.

ANON. 1999c. Hoofde en rade. Beeld: 14, Okt. 21.

ANON. 2001. Transformasie en die onderwys. Mondstuk, 30(324):2.

BENGU, S.M.E. 1998. Budget speech by the Minister of Education in the National Assembly on 11 May.

BEZUIDENHOUT, N. 1999. Staking "gaan oor ego's” en nie salarisse. Beeld: 12, Aug. 25.

DU PREEZ, L. 1999. Onderwysers dra by tot swak uitslae in Noordwes. Beeld: 12, Sept. 15.

ERASMUS, E. 1999. Nog leerkragte dalk vas oor "kwalifikasies". Beeld: Okt. 14.

FOWLER, S. 1991. A Christian voice among students and scholars. Potchefstroom : IRS.

GREY, J. 2001. Scared educators get paid for doing nothing. The Teacher, 5(6):1, June. 
HERSIENE NASIONALE KURRIKULUM/REVISED CURRICULUM STATEMENT. Konsep gepubliseer deur die Departement van Onderwys. Pretoria. Julie 2001.

JOUBERT, J. 1998. Vakbonde bekyk regsimplikasies van vigsbeleid in skole. Beeld: 2, Des. 18.

KLAPWIJK, J. 1987. Antithesis, Synthesis and the Idea of Transformational Philosophy. Philosophiae Reformata, 51:138-152.

LOOTS, Z.B. 1992. Die onderwys as professie. (In Van der Westhuizen, P.C., red. Die beginneronderwyser. 'n Bestuursmatig-juridiese perspektief. Durban : Butterworth. p. 11-34.)

MALHERBE, E.F.J. 1995. Die onderwysbepalings van die 1993 Grondwet. Tydskrif vir Suid-Afrikaanse Reg, 1:1-14.

MENTZ, P.J. 1999. Die invloed van verandering in die onderwys op die gehalte van werklewe van onderwysers. Verslag aan die Sentrum vir Wetenskapsontwikkeling : Potchefstroom. (Projeknommer 15/1/3/16/0101.)

MIDDLETON, J.R. \& WALSH, B.J. 1995. Truth is stranger than it used to be. Biblical faith in a postmodern age. Downers Grove : InterVarsity Press.

NAPOSA (National Professional Teachers' Organisation). 2001. Update. April-August 2001.

NTOMBELA, B.C. 1999. Try being a strict principal and you may lose your life. The Teacher: 3, Feb.

OOSTHUIZEN, I.J., ed. 1998. Aspects of educational law. Pretoria : Van Schaik.

OPPELT, P. 2001. Stick it out and you won't be sorry. The Sunday Times: Jan. 28.

RADEMEYER, A. \& ERASMUS, E. 1999. Beheerrade, onnies moenie in mekaar se sake krap. Beeld: 15, Okt. 20.

RICCI, D 2001. "Relevance" in education will dull the young imagination. The Sunday Times: Nov. 11.

STEENKAMP, L. 1999. Cosas - leerlinge saai chaos in middestad. Beeld: 2, Aug. 25.

SUID-AFRIKA. 1996a. Die Suid-Afrikaanse Skolewet, 84 van 1996. Pretoria : Staatsdrukker.

SUID-AFRIKA. 1996b. Grondwet van die Republiek van Suid-Afrika, 108 van 1996. Pretoria : Staatsdrukker.

SUID-AFRIKA. 1996c. Wet op Nasionale Onderwysbeleid van Suid-Afrika, 27 van 1996. Pretoria : Staatsdrukker.

TAYLOR, N. \& VINJEVOLD, P. 1999. Getting learning right. Wits University : Joint Education Trust.

TEMPELHOFF, E. 1999. Ouers moet hande vat om sterk skole te bou sê Bond. Beeld: 4, Mei 3.

VAN BRUMMELEN, H. 1988 Walking with God in the classroom. Burlington : Welch Publishing Company.

VAN DER WESTHUIZEN, P.C. \& OOSTHUIZEN, I.J. 1989. Ontologiese perspektief op onderwysreg. Suid-Afrikaanse Tydskrif vir Opvoedkunde, 9(4):743-751.

VAN DER WESTHUIZEN, P.C., MENTZ, P.J., MOSOGE, M.J., NIEUWOUDT, H.D., STEYN, H.J., LEGOTLO, M.W., MAAGA, M.P \& SEBEGO, G.M. 1999. A quantitative analysis of the poor performance of Grade 12 students in 1997. South African Journal of Education, 19(4):315-319.

VAN WOUDENBERG, R. 1992. Gelovend denken. Amsterdam : Buijten \& Schipperheijn. 


\section{Kernbegrippe:}

onderwysergeborgenheid

professionaliteit in die onderwys

\section{Key concepts:}

professionalism in education/teaching

teacher safety/security 